Témoigner Témoigner. Entre histoire et mémoire

Getuigen Revue pluridisciplinaire de la Fondation Auschwitz

$121 \mid 2015$

Violences radicales en scène

Debarati Sanyal. Memory and Complicity: Migrations of Holocaust Remembrance

New York: Fordham University Press, 2015

Dario Miccoli

\title{
OpenEdition
}

Journals

Electronic version

URL: https://journals.openedition.org/temoigner/3658

DOI: $10.4000 /$ temoigner.3658

ISSN: 2506-6390

Publisher:

Éditions du Centre d'études et de documentation Mémoire d'Auschwitz, Éditions Kimé

Printed version

Date of publication: 1 October 2015

Number of pages: 201-202

ISSN: 2037-4183

Electronic reference

Dario Miccoli, "Debarati Sanyal. Memory and Complicity: Migrations of Holocaust Remembrance",

Témoigner. Entre histoire et mémoire [Online], 121 | 2015, Online since 01 October 2016, connection on

04 February 2022. URL: http://journals.openedition.org/temoigner/3658 ; DOI: https://doi.org/

10.4000/temoigner.3658

This text was automatically generated on 4 February 2022.

Tous droits réservés 


\section{Debarati Sanyal. Memory and Complicity: Migrations of Holocaust Remembrance}

New York: Fordham University Press, 2015

Dario Miccoli

\section{REFERENCES}

Debarati Sanyal. Memory and Complicity: Migrations of Holocaust Remembrance. New York: Fordham University Press, 2015, 341 pages

1 Over the last few years a number of interesting works that address the issue of Holocaust remembrance vis-à-vis globalization, decolonization and their respective legacies of trauma and violence have been published. These include Rothberg's Multidirectional Memory: Remembering the Holocaust in the Age of Decolonization (2009), The Holocaust and Memory in the Global Age (2006) by Levy and Sznaider or Silverman's Palimpsestic Memory: The Holocaust and Colonialism in French and Francophone Fiction and Film (2013). Drawing upon an original corpus of French (and Francophone) literary texts and films, Debarati Sanyal - professor of French literature at the University of California, Berkeley -proposes a nuanced reading of events as different as the Holocaust, the Algerian war, the post-9/11 US war on terror. Her aim is to show the vitality of what she calls proximate memory that is a memory attentive both to the contiguity and the indelible distance that historical events share.

2 The first chapter, "A Soccer Match in Auschwitz: Passing Trauma in Holocaust Studies" examines the work of Giorgio Agamben and other theorists, reading it against the background of Primo Levi's grey zone. Sanyal argues that Agamben's categories of state of exception and bare life might be problematic insofar as they contribute to turn the "concentrationary imagery [into] a paradigm that illustrates a universal rule" (47). This imagery should instead be deployed as a kind of allegory that helps us to grasp the 
political value and the ethical limits of comparing different histories of violence and genocide.

In order to put this theoretical framework into practice, the second chapter "Concentrationary Migrations in and around Albert Camus "tracks the plague as a figure for intertwined histories of occupation and terror in Camus' literary oeuvre. Focusing on La Peste (1947), La Chute (1956) and other texts, Sanyal argues that Camus' allegories are always multidirectional: they ask readers to look at more than one history. In doing so, she demonstrates how both the Holocaust and colonialism lie beneath Camus' words and the post-war French cultural landscape more generally, functioning as "noeuds de mémoire, historical palimpsests and vectors of political awareness" (96) that migrate beyond the borders of the nation and across time and space. Such a reading of Camus' oeuvre therefore opens up new and parallel interpretations of the European and Maghrebine past, of their divergences as well as of their intersections.

"Auschwitz as Allegory: From Night and Fog to Guantánamo Bay" shifts the analysis to film and visual culture. In this chapter, Sanyal analyzes Alain Resnais' 1955 documentary From Night and Fog- which looked at Auschwitz in relation to colonial Algeria - and follows its visual legacies first in Sembène Ousmane's 1988 movie Camp de Thiaroye, set in a Senegalese transit camp for returning colonial soldiers, and then in recent iconographic material of the Guantánamo Bay Detention Camp. Thanks to this diachronic approach, Sanyal puts into dialogue "subsequent allegorizations of the concentrationary experience" (103) to show both the political vitality and the ethical risks of such comparisons, calling for an attentive reading of different historical junctures.

Jean-Paul Sartre's play Les Séquestrés d'Altona (1958) is at the centre of the fourth chapter, "Crabwalk History: Torture, Allegory, and Memory in Sartre". Sanyal discusses it in conjunction with texts by Robert Antelme, Frantz Fanon, Aimé Césaire and works of art by the painter Roberto Matta. Her goal is to investigate "Sartre's tropology of torture in dialogue with contemporaneous reflections on the relationship between the Nazi genocide and torture in late colonial France" (151).She proposes the notion of crabwalk history - inspired by Sartre and by Günter Grass' novel Im Krebsgang (2002) - as an alternative figure, which just like crabs moves across time and space and puts disparate events into dialogue. As in the previous chapter, the goal is to show that even though the history of the Nazi genocide, of colonialism and of postcolonial forms of imperial domination can inform one another, they cannot be abstracted into a same historical paradigm.

6 The fifth chapter, "Reading Nazi Memory in Jonathan Littell's The Kindly Ones" investigates one of the most controversial French novels of the last decade. Les Bienveillantes (2006) by Littell is the first-person account of a (fictional) SS officer through the rise and fall of Nazi Germany. Whereas some commentators viewed it as a form of revisionist and disturbing intimacy with the perpetrators, Sanyal contends that Littell's novel is alert to "the knotted and dangerous intersections that are the legacy of the Shoah" (210). Written in the context of what French historian Annette Wieviorka termed l'ère du témoin, dominated by postmemory more than memory, Les Bienveillantes posits complicity as a form of critical involvement with a past whose violent legacies are never entirely foreign. 
7 The last chapter of the book, "Holocaust and Colonial Memory in the Age of Terror: Assia Djebar and Boualem Sansal", is dedicated to the novels Les Nuits de Strasbourg (1997) by Djebar and Le Village de l'Allemand (2008) by Sansal - two renowned Francophone Algerian authors. Djebar's Les Nuits de Strasbourg proposes Strasbourg as a metaphor for a new transnational Europe, that, however, is still haunted by a history of violence that struggles to go away and where contrasting pasts and memories resist to assimilation within hegemonic narratives. On the other hand, Le Village de l'Allemand by Sansal tells the story of a Nazi officer who took part to the Algerian liberation struggle and converted to Islam. The novel then builds up an itinerary of violence that consciously yet also problematically, according to Sanyal - connects Nazism to radical Islamic ideas, but does not discuss the roles and impact of colonialism on Algerian society. By analyzing these two texts, Sanyal shows the possibilities and the risks at play when "certain histories are valorized at the expense of others" (262), in times of polarized tension between Islam and the West.

8 In conclusion, Memory and Complicity is a sophisticated book that shows the great potential of the so-called transcultural memory studies. Even though the theoretical palimpsest - to utilize a term that Sanyal recalls in the introduction - needed in order to fully grasp her argument can at times seem almost too vast and dense, the author strives to express it in clear terms, accompanying the reader in a fascinating intellectual tour de force. Sanyal rightly calls for an attentive reading of the legacy of the Holocaust and warns against an uncritical juxtaposition of different histories of genocide and violence. In an era dominated by a number of guerres de mémoires and by the emergence of new forms of religious and ethnic discrimination, this is a caveat that should neither be forgotten nor underestimated.

\section{AUTHORS}

\section{DARIO MICCOLI}

Aix-Marseille Université 